\title{
Stable isotope analysis reveal hidden reliance on scyphozoan jellyfish in a commensal fish: editorial comment on the feature article by D'Ambra et al.
}

\author{
Chris Harrod
}

Received: 27 October 2014 / Accepted: 29 October 2014 / Published online: 8 November 2014

(C) Springer-Verlag Berlin Heidelberg 2014

We know very little about the ecology of jellyfish and other gelatinous zooplankton and how they interact with other taxa: many biologists consider that their role in ecosystems is likely underestimated (Pauly et al. 2009). As citizens and marine biologists, we are continually exposed to stories (via the news media and even the scientific literature) where jellyfish are shown in a negative light and even as indicators of impending ecological doom. The negative impacts of jellyfish blooms on aquaculture and fisheries are well documented, but sometimes I feel that we are approaching a point where (to some observers) the presence of normal densities of jellyfish in marine ecosystems is considered an indication of perturbation, even though jellyfish and associated taxa are natural components of such systems.

Some marine biologists have worked hard to counter the consistent negative spin regarding jellyfish. Condon et al. (2013) examined the veracity of the well-reported global rise of jellyfish, and in a recent book chapter, Doyle et al. (2014) highlighted the positive side of jellyfish in terms of their important ecological roles and the goods and services they provide to human society. The wider public are well aware of the importance of jellyfish as prey to some charismatic megafauna including leatherback turtles and sunfish (although recent studies show that relationship between jellyfish and sunfish may be less clear than previously thought (Harrod et al. 2013; Nakamura and Sato 2014)). Less well known, at least by those not working on jellyfish, is the fact that individual jellyfish are

Communicated by U. Sommer.

C. Harrod $(\bowtie)$

Instituto de Ciencias Naturales Alexander Von Humboldt,

Universidad de Antofagasta, Avenida Angamos 601,

Antofagasta, Chile

e-mail: chris@harrodlab.net often found in association with a diverse range of commensal organisms, including invertebrates (e.g. crabs, amphipods) and early life stages of fish, many of which are ecologically and economically important (Doyle et al. 2014).

A long debate has revolved around the precise form of the primary relationship between commensal taxa and their jellyfish hosts. Does the host provide habitat in the form of a refuge for commensal taxa in the otherwise open pelagic habitat, allowing them to feed on prey from the surrounding waters whilst providing protection from predators? This seems reasonable, especially when the mobile refuge comes equipped with the added capacity to sting or kill potential predators. Alternatively, the host may also provide a source of food for commensal taxa: indeed commensal fish and other taxa have been observed to feed on their jellyfish hosts. Pulling the relative importance of these potential relationships (which are not mutually exclusive) apart has been complicated by the fact that gelatinous tissues are digested quickly and are not easily identified in gut or stomach contents (Arai et al. 2003). Furthermore, such tissues are considered to be of limited nutritional value (Pitt et al. 2009), and it has been generally considered that they do not contribute significantly to the diet of commensal fish (Purcell and Arai 2001). Hence, to date, many workers have concluded that the primary interaction between commensal taxa and their jellyfish hosts is likely to be one of the provisions of habitat.

The feature article by Isabella D'Ambra and her coauthors successfully turns this assumption on its head, at least in the case of their study system. In a short but solid study, they examine the assimilated diet of Atlantic bumper (Chloroscombrus chrysurus), an abundant carangid fish from the Gulf of Mexico that lives commensally with jellyfish hosts (Aurelia sp. and Drymonema larsoni) during the fish's juvenile life stage (Tolley 1987). Rather than examining stomach contents, D'Ambra et al. compared the stable 
isotope ratios of carbon $\left(\delta^{13} \mathrm{C}\right)$ and nitrogen $\left(\delta^{15} \mathrm{~N}\right)$ in the tissues of the fish with that of various putative foods including the jellyfish host and pelagic plankton. Their results are striking and through the use of isotope mixing models, the authors provide strong evidence that between 80 and $100 \%$ of the carbon and nitrogen in juvenile Atlantic bumper muscle tissue was derived from the jellyfish host.

Although the consumption of jellyfish hosts has been observed previously, this is the first time that a reliable estimate of the scale of consumption of host tissues has been made in the sensitive early life stage of a commercially important fish. Furthermore, the authors have revealed that this fish relies primarily on host jellyfish for the growth of somatic tissues, raising the issue that a major trophic link in the well-studied Gulf of Mexico ecosystem has been overlooked. Worldwide, numerous other economically and ecologically important fishes are associated with jellyfish hosts, and the authors rightly highlight that such potential trophic relationships are in need of re-examination and if shown to exist, to be included in ecosystem models.

The study by D'Ambra and her colleagues joins a limited pool of isotopic studies that also show assimilation of jellyfish host tissues by of commensal crabs and amphipods (Towanda and Thuesen 2006; Fleming et al. 2014). As such, the prevailing view that commensal taxa primarily use their hosts as habitat is clearly due for some rethought. Finally, as an isotope ecologist, I am happy to note how this study highlights the utility of stable isotope analysis to reveal cryptic trophic relationships that have the potential to completely change our understanding of even well-studied taxa and ecosystems.

\section{References}

Arai MN, Welch DW, Dunsmuir AL, Jacobs MC, Ladouceur AR (2003) Digestion of pelagic Ctenophora and Cnidaria by fish. Can J Fish Aquat Sci 60:825-829. doi:10.1139/f03-071
Condon RH, Duarte CM, Pitt KA, Robinson KL, Lucas CH, Sutherland KR, Mianzan HW, Bogeberg M, Purcell JE, Decker MB, Uye SI, Madin LP, Brodeur RD, Haddock SHD, Malej A, Parry GD, Eriksen E, Quiñones J, Acha M, Harvey M, Arthur JM, Graham WM (2013) Recurrent jellyfish blooms are a consequence of global oscillations. PNAS 110:1000-1005. doi:10.1073/p nas. 1210920110

D’Ambra I, Graham WM, Carmichael RH, Hernandez FJ Jr (2014) Fish rely on scyphozoan hosts as a primary food source: evidence from stable isotope analysis. Mar Biol. doi:10.1007/s00227-0142569-5 (this issue)

Doyle TK, Hays GC, Harrod C, Houghton JDR (2014) Ecological and societal benefits of jellyfish. In: Lucas CH, Pitt KA (eds) Jellyfish blooms. Springer, Germany

Fleming NEC, Harrod C, Griffin DC, Newton J, Houghton JDR (2014) Scyphozoan jellyfish provide short-term reproductive habitat for hyperiid amphipods in a temperate near-shore environment. Mar Ecol Prog Ser 510:229-240. doi:10.3354/meps10896

Harrod C, Syväranta J, Kubicek L, Cappanera V, Houghton JDR (2013) Reply to Logan \& Dodge: 'Stable isotopes challenge the perception of ocean sunfish Mola mola as obligate jellyfish predators'. J Fish Biol 82:10-16

Nakamura I, Sato K (2014) Ontogenetic shift in foraging habit of ocean sunfish Mola mola from dietary and behavioral studies. Mar Biol 161:1263-1273. doi:10.1007/s00227-014-2416-8

Pauly D, Graham W, Libralato S, Morissette L, Palomares MD (2009) Jellyfish in ecosystems, online databases, and ecosystem models. Hydrobiologia 616:67-85

Pitt K, Welsh D, Condon R (2009) Influence of jellyfish blooms on carbon, nitrogen and phosphorus cycling and plankton production. Hydrobiologia 616:133-149

Purcell JE, Arai MN (2001) Interactions of pelagic cnidarians and ctenophores with fish: a review. Hydrobiologia 451:27-44. doi:10 .1023/a:1011883905394

Tolley SG (1987) Association of young Chloroscombrus chrysurus (Pisces: Carangidae) with the jellyfish Aurelia aurita. Copeia 1987:216-219. doi:10.2307/1446057

Towanda T, Thuesen EV (2006) Ectosymbiotic behavior of Cancer gracilis and its trophic relationships with its host Phacellophora camtschatica and the parasitoid Hyperia medusarum. Mar Ecol Prog Ser 315:221-236. doi:10.3354/meps315221 